\title{
PENGARUH BERBAGAI JENIS PENGGUMPAL PADAT TERHADAP MUTU KOAGULUM DAN VULKANISAT KARET ALAM
}

\author{
Effect of Various Type of Solid Coagulants on the Quality of Coagulum and \\ Vulcanized Natural Rubber
}

\author{
Hani HANDAYANI
}

Pusat Penelitian Karet

Jalan Salak No.1 Bogor 16151

E-mail: hani_handayani@bptkbgr.com

Diterima : 5 Juli 2013 / Direvisi : 17 September 2013 / Disetujui : 2 Desember 2013

\begin{abstract}
Quality of raw rubber material is low and varies because the unavailability of proper coagulant to farmer level. Use proper coagulant to produce good quality rubber is not fully carried out. This research studied the influence of various solid coagulants on quality of coagulum and vulcanized natural rubber. Coagulant was added to preserved latex $(7 \mathrm{~g} / \mathrm{kg}$ dry rubber). The coagulum was allowed for two weeks, then milled and dried at $100^{\circ} \mathrm{C}$ for 2-3 hours. Chemical properties of dry rubber was tested. Further, the rubber was made into ASTM 2 A vulcanizate. The rubber compounds were tested its vulcanization characteristic and the vulcanizate were tested its mechanical properties. Formic acid was used as a comparison. The results showed that the use of organic acids and salts as solid coagulant has advantages and disadvantages of each. The combination of an acid with an inorganic salt is expected to give better results so as the quality of rubberwill increases.
\end{abstract}

Keywords : Natural rubber, coagulant, vulcanizate, rubbergood

\section{Abstrak}

Mutu bahan olah karet masih rendah dan bervariasi akibat tidak tersedianya koagulan yang baik sampai ke tingkat petani. Penggunaan koagulan yang tepat untuk menghasilkan bokar bermutu baik masih belum sepenuhnya dilakukan akibat belum tersedianya koagulan yang mudah didistribusikan, kompetitif dari segi harga, dan tidak merusak mutu karet. Penelitian ini mempelajari pengaruh berbagai jenis penggumpal padat terhadap mutu koagulum dan vulkanisat karet alam. Bahan penggumpal ditambahkan ke dalam lateks kebun berpengawet ammonia pada dosis $7 \mathrm{~g} / \mathrm{kg}$ karet. Lateks yang telah diberi perlakuan dibiarkan menggumpal selama dua minggu, selanjutnya karet digiling dan dikeringkan dalam oven pada suhu $100^{\circ} \mathrm{C}$ selama 2-3 jam. Karet kering diuji sifat kimianya (PRI, kadar kotoran, kadar abu, dan kadar zat menguap), setelah itu dibuat vulkanisat dengan resep kompon ASTM 2A. Kompon karet diuji karakteristik vulkanisasinya dengan rheometer, kemudian vulkanisat diuji sifat mekanik (kekuatan tarik, perpanjangan putus, modulus $300 \%$ dan kekerasan). Sebagai pembanding digunakan asam format. Hasil penelitian menunjukkan bahwa penggunaan asam organik dan garam anorganik sebagai bahan penggumpal memiliki kelebihan dan kekurangan masingmasing. Kombinasi antara bahan asam dengan garam anorganik diharapkan dapat memberikan hasil yang lebih baik sehingga mutu bahan olah karet akan meningkat.

Kata kunci : Karet alam, bahan penggumpal, vulkanisat, barang jadi

\section{PENDAHULUAN}

Karet alam merupakan komoditas tradisional sekaligus komoditas ekspor yang berperan penting sebagai penghasil devisa dari sub-sektor perkebunan, dan menjadi tumpuan pencaharian bagi banyak keluarga petani. Sebagian besar perkebunan karet di Indonesia adalah perkebunan rakyat ( $\pm 85 \%$ ), yang menyumbang lebih dari $75 \%$ produksi karet nasional. Pada tahun 2011, produksi karet nasional mencapai 3,09 juta ton $(27,68 \%$ dari produksi karet alam dunia) dan menempatkan Indonesia sebagai penghasil karet terbesar kedua setelah Thailand.(Ditjenbun, 2012) Bila produksi karet alam stabil atau bahkan meningkat maka beberapa tahun mendatang Indonesia berpotensi menjadi produsen nomor 1 di dunia.(IRSG, 2011) Pertengahan tahun 2012 kinerja ekspor karet mencapai 5,62 milyar USD dan memberikan sumbangan sebesar $14,58 \%$ terhadap total ekspor non migas (BPS, 2012), menempatkan karet sebagai komoditas penghasil devisa terbesar kedua, setelah CPO, dalam kelompok produk ekspor hasil pertanian dan kehutanan. 
Dalam program pemantapan ekspor dan daya saing karet, Kementerian Perdagangan telah mengeluarkan beberapa kebijakan dalam rangka penyediaan bahan olah komoditi ekspor Standard Indonesian Rubber (SIR) yang bermutu baik dan konsisten. Guna meningkatkan mutu ekspor SIR yang dihasilkan oleh industri crumb rubber maka Kementerian Perdagangan mengeluarkan Permendag No. 53 / M - D A G / PER / $10 / 2009$ tentang Pengawasan Mutu Bahan Olah Komoditi Ekspor Standard Indonesian Rubber yang diperdagangkan. Di samping itu Kemendag juga mengeluarkan Permendag No. 10/MDAG/PER/4/2008 tentang Ketentuan Karet Alam Spesifikasi Teknis Indonesia (SIR) yang diperdagangkan ke Luar Negeri (KNLH, 2007).

Salah satu permasalahan pada karet alam saat ini adalah masih rendahnya mutu bahan olah karet akibat tidak tersedianya koagulan yang baik sampai ke tingkat petani, jumlah kontaminan yang cukup banyak, dan cara penanganan yang kurang bersih. Kondisi ini menyebabkan terjadinya inefisiensi pada waktu pengolahan di pabrik terutama pabrik karet remah. Guna meningkatkan peranan dan daya saing komoditas karet di pasar Internasional, diperlukan peningkatan daya saing dengan memperbaiki citra mutu bahan olah karet dan efisiensi biaya olah. Oleh karena itu Kementerian Pertanian telah mengeluarkan Peraturan Menteri Pertanian Nomor 38/Permentan/OT.140/8/2008 tentang Pedoman Pengolahan dan Pemasaran Bahan Olah Karet (Bokar) dimana peraturan ini dijadikan pedoman bagi stakeholders dalam kegiatan pengolahan lateks menjadi bokar yang sesuai dengan baku mutu. Dalam Permentan tersebut dipersyaratkan penggunaan bahan penggumpal yang dianjurkan agar tidak merusak mutu karet. Akan tetapi penggunaan koagulan yang tepat untuk menghasilkan bokar bermutu baik masih belum sepenuhnya terwujud akibat belum tersedianya koagulan yang mudah didistribusikan, kompetitif dari segi harga, dan tidak merusak mutu karet (Gapkindo, 2011).

Berdasarkan standar mutu bokar yang tercantum dalam SNI 06-2047-2002 tentang Bahan Olah Karet dijelaskan bahwa bahan penggumpal yang dianjurkan dan relatif aman untuk lateks adalah asam format atau bahan lain yang tidak merusak mutu karet misalnya asam asetat (Triwijoso, 1989). Harga kedua bahan penggumpal tersebut relatif mahal dan penanganannya sulit karena berbentuk cair sehingga jarang digunakan oleh petani. Saat ini banyak petani masih menggunakan bahan alami atau kimia yang tidak dianjurkan seperti asam sulfat (cuka para), pupuk TSP, tawas, larutan umbi gadung, dan sari buah nanas untuk menggumpalkan lateks. Alasan utama yang mendasari dikarenakan harga yang murah, kemudahan, dan jaminan ketersediaan, serta dapat menggumpalkan lateks dalam waktu yang relatif cepat meskipun mutu bokar yang dihasilkannya sangat rendah (triwijoso dan Siswantoro, 1989).

Akhir-akhir ini koagulan yang mengandung asam anorganik banyak diproduksi oleh berbagai perusahaan koagulan dan dijual dengan harga yang lebih kompetitif. Pada dasarnya penggumpal lateks jenis ini dapat digunakan sepanjang tidak merusak mutu bahan olah yang dihasilkan. Penggunaan asam anorganik seperti asam sulfat menghasilkan karet yang mutunya cenderung lebih rendah, selain itu penggunaannya di pabrik haruslah melalui pengawasan yang lebih ketat. Berdasarkan ketahanan terhadap oksidasi terutama oleh suhu panas karet hasil koagulasi dengan asam sulfat baik pada dosis 1,76 gram untuk tiap kg karet kering. Penggunaan dosis yang lebih tinggi mengakibatkan mutu karet yang dihasilkan akan menjadi lebih rendah.

Penelitian bertujuan untuk mempelajari pengaruh penggunaan berbagai koagulan padat terhadap sifat-sifat teknis (kimia), karakteristik vulkanisasi, dan sifat fisika vulkanisat karet krep yang digumpalkan dengan koagulan padat tersebut.

\section{BAHAN DAN METODE}

Pengujian dilaksanakan di Laboratorium Penelitian Pusat Penelitian Karet, Bogor pada periode bulan Februari hingga November 2012. Bahan yang digunakan dalam penelitian meliputi lateks kebun klon campuran, asam-asam organik (asam sitrat dan asam oksalat), garamgaram anorganik (kalsium klorida, kalsium 
sulfat, magnesium klorida dan magnesium sulfat), asam format, dan bahan kimia untuk analisis spesifikasi teknis karet remah. Peralatan yang digunakan antara lain: mangkuk sadap, bak penggumpal, mesin giling creeper, oven, dan peralatan pengujian spesifikasi teknis mutu karet remah.

Tahapan percobaan diawali dengan menentukan kadar karet kering (KKK) lateks. Lateks yang telah diketahui KKKnya dimasukkan ke dalam mangkuk penggumpalan.

\section{Pengamatan Penggumpalan}

Bahan penggumpal yang digunakan dalam penelitian ini meliputi asam organik dan garam anorganik. Bahan-bahan tersebut dibuat larutan pada konsentrasi $2,5 \%$. Hasil studi pendahuluan menunjukkan bahwa dosis optimum koagulan yang ditambahkan adalah sebanyak $7 \mathrm{~g} / \mathrm{kg}$ karet. Koagulan ditambahkan ke dalam $150 \mathrm{ml}$ lateks kebun yang sudah diawetkan dengan amoniak $(0,02 \%)$. Selama proses penggumpalan, diamati waktu mulai terbentuknya gel, waktu mulai menggumpal, waktu penggumpalan sempurna, warna serum, dan karakteristik koagulum. Sebagai penggumpal pembanding (kontrol) digunakan asam format dan lateks yang digumpalkan secara alami (tanpa penambahan bahan penggumpal).

\section{Analisis Mutu Koagulum Yang Dihasilkan}

Lateks yang telah diberi perlakuan dibiarkan hingga menggumpal sempurna membentuk koagulum. Koagulum selanjutnya diperam selama 2 minggu (14 hari), kemudian digiling dalam mesin creeper hingga membentuk karet krep. Karet krep basah selanjutnya dikeringkan dalam oven pada suhu $100^{\circ} \mathrm{C}$ selama $2-3$ jam. Karet krep kering yang terbentuk diuji nilai PRI (Indeks Ketahanan Plastisitas, Plasticity Retention Index), kadar kotoran, kadar abu, dan kadar zat menguap sesuai dengan SNI 06-19032000 tentang Standard Indonesian Rubber (SIR).

\section{Uji Mutu Pada Vulkanisat Kompon ASTM 2A}

Karet krep yang telah diuji mutu teknisnya kemudian dibuat menjadi vulkanisat dengan resep kompon ASTM 2A Kompon yang dibuat kemudian diuji karakteristik vulkanisasinya dengan rheometer, sedangkan vulkanisat diuji sifat mekaniknya yang meliputi: kekuatan tarik, perpanjangan putus, modulus 300\% dan kekerasan.

\section{HASIL DAN PEMBAHASAN}

\section{Pengamatan Penggumpalan}

Hasil pengamatan proses penggumpalan dan karakteristik koagulum disajikan dalam Tabel 1.

Dari hasil tersebut diketahui bahwa asam organik dapat menggumpalkan lateks lebih cepat dibandingkan dengan garam anorganik. Kedua penggumpalan tersebut berjalan dengan mekanisme yang berbeda. Penggumpalan dengan asam terjadi melalui mekanisme penurunan $\mathrm{pH}$ sedangkan penggumpalan dengan garam anorganik berjalan karena adanya penambahan kation garam sebagai elektrolit. Stabilitas lateks disebabkan oleh adanya selubung protein pada bagian luar yang bermuatan negatif. Pada $\mathrm{pH}$ tertentu muatan positif lateks seimbang dengan muatan negatif (tercapai titik isolistrik). Penambahan asam sampai ke titik isolistrik dapat mengganggu kestabilan lateks sehingga menyebabkan lateks menggumpal. Sementara itu penambahan elektrolit yang mengandung kation (yang muatannya berlawanan dengan partikel karet) ke dalam lateks akan menyebabkan penurunan potensial elektrokinetik sehingga mengakibatkan lateks menggumpal. Penggumpalan lateks melalui mekanisme penurunan $\mathrm{pH}$ ternyata berjalan lebih cepat dibandingkan melalui penambahan elektrolit. Kombinasi antara keduanya diharapkan dapat semakin mempercepat proses penggumpalan lateks. Penggunaan asam kuat tidak disarankan karena berpengaruh buruk pada sifat teknis karet keringnya. Itulah sebabnya dalam penelitian ini hanya digunakan asam-asam lemah.

Untuk masing-masing bahan garam, walaupun bekerja dengan mekanisme yang sama, tetapi kecepatan penggumpalannya berbeda tergantung dari jenis kationnya. Hal ini dipengaruhi oleh afinitas elektron, keelektronegatifan, dan letaknya dalam sistem periodik. Kalsium merupakan unsur 
Tabel 1. Karakteristik penggumpalan lateks yang digumpalkan dengan berbagai bahan penggumpal padat

Table 1. Latex coagulation characteristics which were coagulated with various solid coagulants

\begin{tabular}{ll}
\hline \multicolumn{1}{c}{$\begin{array}{c}\text { Bahan penggumpal } \\
\text { Coagulants }\end{array}$} & \multicolumn{1}{c}{$\begin{array}{c}\text { Hasil pengamatan setelah 2 jam } \\
\text { Observation after 2 hours }\end{array}$} \\
\hline Asam format & Menggumpal sempurna, serum berwarna abu-abu \\
Tanpa bahan (Alami) & Belum menggumpal, masih encer \\
Asam oksalat & Hampir menggumpal seluruhnya \\
Asam sitrat & Hampir menggumpal seluruhnya \\
Kalsium klorida & Hampir menggumpal seluruhnya \\
Kalsium sulfat & Hampir menggumpal seluruhnya \\
Magnesium klorida & Baru menggumpal sebagian \\
Magnesium sulfat & Baru menggumpal sebagian \\
\hline
\end{tabular}

periode 4 sedangkan magnesium periode 3 . Berdasarkan sistem periodik unsur, unsur dalam satu golongan, semakin ke bawah, keelektronegatifannya semakin rendah dan afinitas elektronnya semakin tinggi. Dengan demikian muatan positif ion kalsium lebih besar dibandingkan dengan magnesium. Semakin positif muatannya, kekuatan unsur tersebut untuk menggumpalkan lateks semakin besar.

Selain kation, kekuatan penggumpalan garam-garam tersebut juga sedikit dipengaruhi oleh anionnya. Berdasarkan hasil penelitian diketahui bahwa anion dengan valensi lebih kecil membantu mempercepat proses penggumpalan lebih baik dibandingkan dengan anion valensi yang lebih besar.

\section{Analisis Mutu Koagulum yang Dihasilkan}

Tabel 2 memperlihatkan hasil pengujian yang memenuhi persyaratan mutu dalam SNI 06-1903-2000 tentang karet SIR. Dari Tabel 2 terlihat bahwa plastisitas paling baik diperoleh dari karet yang digumpalkan dengan asam oksalat sedangkan kadar nitrogen paling rendah diperoleh dari karet yang digumpalkan dengan kalsium sulfat.

Kadar zat menguap (Vm) karet menunjukkan sisa uap air dan zat-zat lain seperti serum yang masih ada di dalam karet setelah diuapkan. Adanya zat mudah menguap di dalam karet dapat menyebabkan bau busuk, memudahkan tumbuhnya jamur dan dapat menimbulkan kesulitan saat mencampurkan bahan kimia ke dalam karet pada pembuatan kompon terutama untuk mencampurkan carbon black pada suhu rendah. Semakin tinggi nilai Vm maka mutu karetnya semakin rendah.(Ompusungu dan Darussamin, 1989). Hasil penelitian menunjukkan bahwa nilai $\mathrm{Vm}$ paling rendah diperoleh dari karet yang digumpalkan dengan asam sitrat.

Abu adalah zat anorganik dari sisa hasil pembakaran suatu bahan organik. Penentuan kadar abu berhubungan dengan mineral suatu bahan (Sudarmadji et al., 2003) Kandungan dan komposisi abu atau mineral pada bahan tergantung dari jenis bahan dan cara pengabuannya. Abu di dalam karet mentah terdiri dari oksida logam, dan garam anorganik seperti karbonat, fosfat, sulfat, kalium, magnesium, kalsium, dan beberapa unsur lain. Penggunaan garam anorganik sebagai bahan penggumpal akan menaikkan kabar abu dibandingkan dengan penggunaan asam. Hasil penelitian menunjukkan penggunaan garam anorganik sebagai bahan penggumpal menaikkan kadar abu tetapi nilainya masih memenuhi persyaratan mutu SIR sehingga bisa digunakan. Semakin besar massa molekul relatif dari bahan-bahan anorganik yang ada di dalam karet maka kadar abunya akan semakin tinggi.

Kadar kotoran menunjukkan jumlah bahan bukan karet yang tidak larut dan tidak dapat lolos dari saringan 325 mesh. Adanya kotoran yang tinggi di dalam karet 
Tabel 2. Perbandingan mutu spesifikasi teknis karet krep berdasarkan nilai uji beberapa parameter sifat kimia

Table 2. Comparison of crepe rubber quality based on value of chemical parameter

\begin{tabular}{lcccc}
\hline \multirow{2}{*}{$\begin{array}{c}\text { Bahan penggumpal } \\
\text { Coagulants }\end{array}$} & \begin{tabular}{c} 
Kadar zat \\
menguap \\
Volatile matter \\
\cline { 2 - 5 }
\end{tabular} & $\begin{array}{c}\text { Kadar abu } \\
\text { Ash content } \\
(\%)\end{array}$ & $\begin{array}{c}\text { Kadar } \\
\text { kotoran }\end{array}$ & $\begin{array}{c}\text { Indeks ketahanan } \\
\text { Dirt content } \\
\text { plastisitas } \\
\text { Plasticity retention } \\
\text { index }\end{array}$ \\
\hline Asam format & 0,44 & 0,28 & 0,019 & 75,5 \\
Tanpa bahan (Alami) & 0,34 & 0,34 & 0,005 & 61,3 \\
Asam oksalat & 0,42 & 0,33 & 0,024 & 77,9 \\
Asam sitrat & 0,32 & 0,36 & 0,011 & 64,9 \\
Kalsium klorida & 0,39 & 0,42 & 0,024 & 64,4 \\
Kalsium sulfat & 0,36 & 0,33 & 0,004 & 63,9 \\
Magnesium klorida & 0,45 & 0,31 & 0,014 & 63,3 \\
Magnesium sulfat & 0,41 & 0,31 & 0,008 & 62,7 \\
\hline
\end{tabular}

dapat mengurangi sifat dinamika yang unggul dari vulkanisat karet alam. Semakin tinggi spesifikasinya semakin rendah batas yang diperbolehkan. Lateks kebun yang ditangani dengan tepat umumnya memiliki kadar kotoran yang relatif rendah. Penambahan bahan penggumpal akan meningkatkan kadar kotoran dalam lateks dan karet mentahnya. Hasil penelitian menunjukkan kadar kotoran dari semua karet yang diuji memenuhi spesifikasi SIR 20.

PRI atau Plasticity Retention Index adalah parameter untuk mengukur ketahanan karet mentah terhadap degradasi oleh oksidasi pada suhu tinggi. Semakin tinggi nilai PRI berarti karet semakin tahan terhadap oksidasi. Hasil penelitian menunjukkan bahwa asam oksalat memberikan nilai PRI paling besar dibandingkan dengan bahan lainnya, artinya karet yang digumpalkan dengan asam oksalat lebih tahan terhadap oksidasi dibandingkan dengan bahan lainnya termasuk asam format. Sementara karet yang digumpalkan dengan bahan-bahan garam anorganik cenderung menurun nilai PRI yang berarti kurang tahan terhadap oksidasi. Selain bahan penggumpal, plastisitas karet juga dipengaruhi oleh suhu, waktu, dan proses pemanasan. Pemanasan tidak kontinyu, suhu terlalu tinggi, dan waktu pemanasan yang terlalu lama dapat menurunkan nilai PRI karet secara drastis.

\section{Uji Mutu pada Vulkanisat Kompon ASTM 2A}

Vulkanisat dibuat dengan menggunakan resep kompon standar ASTM 2A (Tabel 3) untuk mengetahui pengaruh bahan penggumpal terhadap sifat fisik karet yang dihasilkannya. Sebelum dibuat vulkanisat, kompon karet terlebih dahulu diuji dalam Rheometer untuk mengetahui proses pematangan dan karakter vulkanisasinya. Hasil pengujian Rheometer disajikan pada Tabel 4.

Tabel 4 menunjukkan bahwa scorch time (waktu pra vulkanisasi, ts2) dan waktu vulkanisasi $\left(t_{90}\right)$ untuk garam kalsium relatif lebih lama dibandingkan garam magnesium. Sementara itu dari golongan asam, asam sitrat memberikan scorch time dan waktu vulkanisasi paling lama. Lamanya waktu vulkanisasi dan scorch time untuk asam sitrat dan garam kalsium menunjukkan bahwa periode peralihan dari kompon menjadi vulkanisat dari karet yang digumpalkan dengan garam kalsium dan asam sitrat lebih lama dari karet yang lainnya. Waktu scorch yang terlalu panjang dapat mengakibatkan kenaikan viskositas kompon sehingga menyulitkan dalam proses pengolahan selanjutnya. Oleh karena itu, semakin pendek waktu scorch akan semakin memudahkan untuk proses pembuatan 
Tabel 3. Susunan formula kompon ASTM 2A

Table 3. Compound formula for ASTM $2 \mathrm{~A}$

\begin{tabular}{lc}
\hline \multicolumn{1}{c}{$\begin{array}{c}\text { Bahan } \\
\text { Material }\end{array}$} & $\begin{array}{c}\text { Komposisi } \\
\text { (bsk) } \\
\text { Composition } \\
\text { (phr) }\end{array}$ \\
\hline Karet alam & 100 \\
ZnO & 5 \\
Asam stearat & 2 \\
CB 330 & 35 \\
TBBS & 0,7 \\
Sulfur & 2,25 \\
\hline
\end{tabular}

Tabel 4. Karakteristik vulkanisasi kompon ASTM 2A

Table 4. Vulcanization characteristics of ASTM 2A compound

\begin{tabular}{|c|c|c|c|c|c|c|}
\hline \multirow[b]{2}{*}{$\begin{array}{c}\text { Bahan penggumpal } \\
\text { Coagulants }\end{array}$} & \multicolumn{6}{|c|}{ Rheometer $\left(\mathrm{T}=150^{\circ} \mathrm{C}\right)$} \\
\hline & $\begin{array}{c}\text { Waktu } \\
\text { (menit) } \\
\text { Time } \\
\text { (minute) }\end{array}$ & $\begin{array}{c}\text { Perbedaan } \\
\text { modulus } \\
\text { torsi } \\
\text { Delta } \\
\text { torque } \\
\text { modulus } \\
\mathrm{S}_{\max }-\mathrm{S}_{\min } \\
(\mathrm{Kg}-\mathrm{cm}) \\
\end{array}$ & $\begin{array}{c}\text { Modulus } \\
\text { torsi } \\
\text { Maksimal } \\
\text { Maximum } \\
\text { torque } \\
\text { modulus } \\
\mathrm{S}_{\max } \\
(\mathrm{Kg}-\mathrm{cm})\end{array}$ & $\begin{array}{l}\text { Modulus } \\
\text { torsi } \\
\text { minimal } \\
\text { Minimum } \\
\text { torque } \\
\text { modulus } \\
\mathrm{S}_{\text {min }} \\
(\mathrm{Kg}-\mathrm{cm})\end{array}$ & $\begin{array}{c}\text { Waktu } \\
\text { vulkanisasi } \\
\text { optimal } \\
\text { (Menit) } \\
\text { Optimum } \\
\text { cure time } \\
\text { t90 } \\
\text { (Minute) }\end{array}$ & $\begin{array}{c}\text { Waktu } \\
\text { pemasakan } \\
\text { dini } \\
\text { (Menit) } \\
\\
\text { Scorch } \\
\text { time } \\
\text { (Minute) }\end{array}$ \\
\hline Asam format & 28,1 & 8,82 & 9,20 & 0,38 & 13,47 & 3,57 \\
\hline $\begin{array}{l}\text { Tanpa bahan } \\
\text { (Alami) }\end{array}$ & 26,8 & 10,31 & 11,08 & 0,77 & 55 & 3,23 \\
\hline Asam oksalat & 30,0 & 9,52 & 10,14 & 0,62 & 12,32 & 3,19 \\
\hline Asam sitrat & 24,1 & 8,04 & 8,48 & 0,44 & 13,57 & 4,08 \\
\hline Kalsium klorida & 27,3 & 7,83 & 8,26 & 0,43 & 14,19 & 4,10 \\
\hline Kalsium sulfat & 27,3 & 9,09 & 9,81 & 0,72 & 15,16 & 3,57 \\
\hline Magnesium klorida & 28,4 & 8,70 & 9,50 & 0,80 & 14,40 & 3,45 \\
\hline Magnesium sulfat & 30,0 & 8,63 & 9,14 & 0,51 & 14,08 & 3,45 \\
\hline
\end{tabular}

barang jadi karet.

Tabel 5 memperlihatkan hasil pengujian sifat fisika vulkanisat. Dari tabel tersebut diketahui bahwa modulus 300\% untuk karet tanpa perlakuan paling tinggi dibandingkan dengan modulus karet yang diberi perlakuan. Hal ini menunjukkan bahwa penggunaan bahan penggumpal menurunkan modulus karet alam. Garam kalsium menurunkan modulus lebih besar dibandingkan dengan garam magnesium dan asam organik.

Sementara itu kekuatan tarik dari karet yang diberi perlakuan lebih tinggi dibandingkan dengan karet yang tidak diberi perlakuan. Dengan demikian penambahan bahan penggumpal dapat memperbaiki mutu karet dengan meningkatnya kekuatan tarik.

Hasil pengujian nilai perpanjangan putus menunjukkan bahwa karet yang tidak diberi perlakuan lebih mudah putus dibandingkan dengan karet yang diberi perlakuan. Perpanjangan putus paling tinggi diperoleh dari karet yang digumpalkan dengan magnesium sulfat. Artinya garam magnesium atau garam sulfat membantu meningkatkan mutu karet melalui peningkatan nilai perpanjangan putus.

Pemberian perlakuan melalui penambahan penggumpal sepertinya tidak 
Tabel 5 Sifat fisik vulkanisat kompon ASTM 2A

Table 5 Physical properties of Vulcanized ASTM 2A

\begin{tabular}{|c|c|c|c|c|}
\hline \multirow[b]{2}{*}{$\begin{array}{l}\text { Bahan penggumpal } \\
\text { Coagulants }\end{array}$} & \multicolumn{4}{|c|}{$\begin{array}{c}\text { Sifat mekanik } \\
\text { Mechanical properties }\end{array}$} \\
\hline & $\begin{array}{c}\text { Modulus } \\
300 \% \\
\left(\mathrm{~N} / \mathrm{mm}^{2}\right)\end{array}$ & $\begin{array}{l}\text { Kekuatan tarik } \\
\text { Tensile strength } \\
\left(\mathrm{N} / \mathrm{mm}^{2}\right)\end{array}$ & $\begin{array}{c}\text { Perpanjangan putus } \\
\text { Elongation at break } \\
(\%)\end{array}$ & $\begin{array}{c}\text { Kekerasan } \\
\text { Hardness } \\
\text { (Shore A) }\end{array}$ \\
\hline Asam format & 7,5 & 18,6 & 520 & 55 \\
\hline Tanpa bahan (Alami) & 9,4 & 18,0 & 470 & 58 \\
\hline Asam oksalat & 8,1 & 20,0 & 520 & 55 \\
\hline Asam sitrat & 7,6 & 20,4 & 540 & 53 \\
\hline Kalsium klorida & 6,5 & 16,7 & 510 & 53 \\
\hline Kalsium sulfat & 7,4 & 21,3 & 560 & 53 \\
\hline Magnesium klorida & 6,8 & 20,9 & 560 & 53 \\
\hline Magnesium sulfat & 7,3 & 21,3 & 560 & 54 \\
\hline
\end{tabular}

terlalu berpengaruh terhadap kekerasan. Hal ini terbukti dengan nilai kekerasan hasil pengujian yang cenderung sama atau tidak terlalu berbeda antara karet yang satu dengan karet yang lainnya. Akan tetapi jika dibandingkan dengan karet yang tidak diberi perlakuan, nilainya relatif lebih rendah, berarti bahan penggumpal menurunkan kekerasan karet.

\section{KESIMPULAN DAN SARAN}

Penggunaan asam organik dan garam anorganik sebagai bahan penggumpal memiliki kelebihan dan kekurangan. Kombinasi antara bahan asam dengan garam anorganik diharapkan dapat memberikan hasil yang lebih baik sehingga mutu bahan olah karet (Bokar) meningkat. Penambahan penggumpal sangat disarankan untuk mempercepat proses penggumpalan sehingga dapat mempersingkat waktu pengolahan juga meningkatkan mutu dari karet yang dihasilkannya.

\section{DAFTAR PUSTAKA}

Badan Pusat Statistik. 2012. Ekspor-Impor Karet. Badan Pusat Statistik, Jakarta.

Direktorat Jenderal Perkebunan. 2012. Statistik Perkebunan Indonesia 20102012: Karet. Kementerian Pertanian, Direktorat Jenderal Perkebunan, Jakarta.
Gabungan Perusahaan Karet Indonesia (Gapkindo). 2011. List of Members. Gapkindo, Jakarta.

International Rubber Study Group (IRSG). 2011. Global Outlook of Natural Rubber Supply and Demand. International Rubber Study Group, Singapore.

Kementerian Negara Lingkungan Hidup. 2007. Buku Panduan Produksi Bersih Industri Crumb Rubber. KNLH, Jakarta.

Ompusunggu, M. dan A. Darussamin. 1989. Pengetahuan Umum Lateks. Balai Penelitian Perkebunan, Bogor.

Sudarmadji, S., H. Bambang, dan Suhardi. 2003. Analisa Bahan Makanan dan Pertanian. Liberty, Yogyakarta.

Triwijoso, S.U., Siswantoro, O. 1989. Pedoman Teknik Pengawetan dan Pemekatan Lateks Hevea. Balai Penelitian Perkebunan, Bogor.

Triwijoso, S.U. 1989. Pengetahuan Umum Tentang Lateks Hevea. Balai Penelitian Perkebunan, Bogor. 